\title{
Atypical presentation of a vertical penile fracture
}

\author{
Sam Hughes (1) ,' Wissam Elbaroni, ${ }^{2}$ John O'Donoghue, ${ }^{3}$ Marc Williams ${ }^{4}$
}

${ }^{1}$ Urology, Yorkshire and the Humber Postgraduate Deanery, York, UK

${ }^{2}$ Urology, Belfast City Hospital Health and Social Services Trust, Belfast, UK

${ }^{3}$ Urology, Southern Health and Social Care Trust, Portadown, UK ${ }^{4}$ Radiology, Southern Health and Social Care Trust, Portadown, UK

\section{Correspondence to}

Dr Sam Hughes;

sam.hughes2@nhs.net

Accepted 10 June 2021

\section{DESCRIPTION}

A penile fracture is defined as a tear of the tunica albuginea, surrounding the corpus cavernosa. It occurs when the erect penis is subjected to an abnormal 'bending' force, inducing an acute increase in intracavernosal pressures, exceeding the tensile strength of the tunica albuginea, which is approximately $1500 \mathrm{~mm} \mathrm{Hg}$, resulting in a tear, or so called 'fracture. ${ }^{12}$

Up to $88.5 \%$ of penile fractures occur during sexual intercourse, with a 20 -year retrospective study concluding 'doggy style' and 'man on top' as the two main etiological positions. ${ }^{34}$ Other lesser reported causes include masturbation, sleeping prone and 'taqaandan' (the practice of forcible detumescence performed primarily in Middle Eastern countries). ${ }^{5}$

This injury is most prevalent among men in their 40s, whom classically report a 'popping' sensation and immediate detumescence, following blunt trauma. On examination, the penis will be grossly swollen and ecchymotic (the so-called 'eggplant' sign) with a palpable 'rolling' sign. In up to $71 \%$ of cases, it is the right corpora which fractures, causing the penis to bend to the left. ${ }^{67}$

The British Association of Urological Surgeons recommend operative intervention within 24 hours, to reduce the risk of long-term complications including erectile dysfunction, excessive penile curvature or urethral stenosis. ${ }^{8}$ A penile MRI is not essential in confirming the diagnosis (especially if it is likely to delay operative intervention), however there is growing evidence supporting its role, particularly if there is concern regarding urethral involvement. ${ }^{9}$

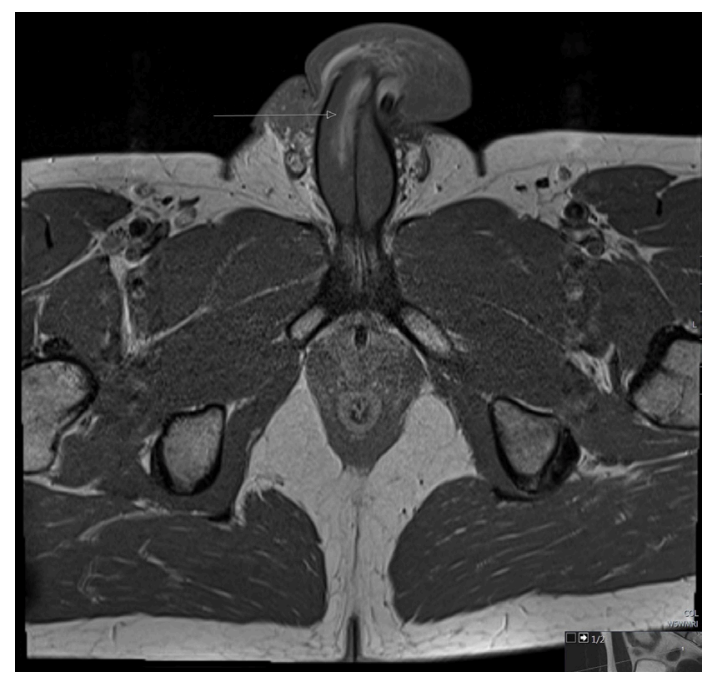

Figure 1 Axial T1 sequences post gadolinium with fat reduction.

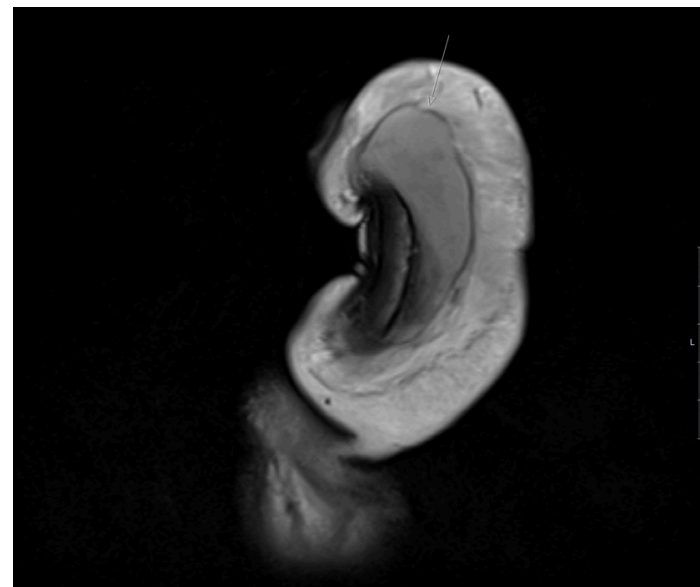

Figure 2 A coronal oblique T2 sequence demonstrates the associated haematoma which abuts the distal right corpus cavernosum.

In July 2020, a PubMed literature review confirmed that all documented cases in the English language, report a 'transverse' fracture of the tunica albuginea. ${ }^{13610-12}$ In turn, we present the first documented case of a vertical penile fracture, confirmed on MRI, sustained by a 40 -year-old man during sexual intercourse.

The patient reported that his penis buckled against his partner's perineum. Interestingly, he described a gradual detumescence, with moderate swelling but no 'popping' sensation. Moreover, there was no palpable 'rolling' sign on examination. Given the presentation, a penile MRI was deemed appropriate in order to exclude a ruptured dorsal vessel and/or suspensory ligament.

The MRI confirmed a vertical disruption of the tunica albuginea at the ventral aspect of the right corpus cavernosum, along the medial third of the penile shaft (see figures 1 and 2). Guided by the MRI, the surgeon was able to target his exploration, confirming that indeed there was a $3 \mathrm{~cm}$ vertical tear. Unfortunately, due to COVID-19 restrictions, medical photography was prohibited.

Based on our literature review of the studies which specifically documented the fracture pattern, all were noted as being transverse, meaning that all other findings were based on transverse fractures and not vertical. Not only does this highlight the rarity of this case, but it also raises the question: Does a vertical penile fracture pattern alter either the presentation or long-term outcomes following operative repair?

Of course, more work is required to answer this question, however based on this case, it would appear that a vertical fracture is not associated with the classical features of a penile fracture, 
namely immediate detumescence, a 'popping' sensation, gross ecchymosis and a palpable rolling defect. In terms of long-term outcomes, we will compare this patient's recovery to that of the literature. Reassuringly however, this patient was able to resume sexual activity within 6 months of the injury, achieving erections of the same quality to those prior to the injury, denying any penile curvature or significant palpable scarring.

\section{Learning points}

- A penile fracture is a urological emergency requiring operative intervention within the first 24 hours of injury.

- A 'popping' sensation followed by immediate detumescence, with a palpable 'rolling' sign are classical presenting features of a penile fracture.

- As the first documented example of a vertical penile fracture this case raises the question: Does a vertical penile fracture pattern alter either the presentation or long-term outcomes following operative repair?

Contributors Dr SH was the first author, along with WE whom together, conducted the literature review. Guided by the primary surgeon in the case, consultant urologist: JO'D. Dr MW, consultant radiologist, reported the penile MRI, confirming the diagnosis of a vertical penile fracture.

Funding The authors have not declared a specific grant for this research from any funding agency in the public, commercial or not-for-profit sectors.

Competing interests None declared.
Patient consent for publication Obtained.

Provenance and peer review Not commissioned; externally peer reviewed.

\section{ORCID iD}

Sam Hughes http://orcid.org/0000-0002-3655-131X

\section{REFERENCES}

1 Mirzazadeh M, Fallahkarkan M, Hosseini J. Diagnosis and management in Iran: a narrative review. Trans/ Androl Urol 2017;6:158-66.

2 Bitsch M, Kromann-Andersen B, Schou J, et al. The elasticity and the tensile strength of tunica albuginea of the corpora cavernosa. J Urol 1990;143:642-5.

3 Barros R, Hampl D, Cavalcanti AG, et al. Lessons learned after 20 years' experience with penile fracture. Int Braz J Urol 2020;46:409-16.

4 Barros R, Schulze L, Ornellas AA, et al. Relationship between sexual position and severity of penile fracture. Int J Impot Res 2017;29:207-9.

5 Falcone M, Garaffa G, Castiglione F, et al. Current management of penile fracture: an up-to-date systematic review. Sex Med Rev 2018;6:253-60.

6 Ateyah A, Mostafa T, Nasser TA, et al. Penile fracture: surgical repair and late effects on erectile function. J Sex Med 2008;5:1496-502.

7 Pandyan GVS, Zaharani AB, Al Rashid M. Fracture penis: an analysis of 26 cases. ScientificWorldJournal 2006;6:2327-33.

8 Rees RW, Brown G, Dorkin T, et al. British Association of Urological Surgeons (BAUS) consensus document for the management of male genital emergencies - penile fracture. BJU Int 2018;122:26-8.

9 Abolyosr A, Moneim AEA, Abdelatif AM, et al. The management of penile fracture based on clinical and magnetic resonance imaging findings. BJU Int 2005;96:373-7.

10 Nale D, Nikić $\mathrm{P}$, Vuković I, et al. [Surgical or conservative treatment of penile fracture]. Acta Chir lugos/ 2008;55:107-14.

11 Mensah JE, Morton B, Kyei M. Early surgical repair of penile fractures. Ghana Med J 2011;44.

12 Singh P, McLeavy C, Lyttle M. Penile fracture. Vol 22 No 4 [Internet]. urologynews. uk.com, 2018. Available: https://www.urologynews.uk.com/media/10774/uromj18penilefracture.pdf [Accessed 7 Jul 2020].

Copyright 2021 BMJ Publishing Group. All rights reserved. For permission to reuse any of this content visit

https://www.bmj.com/company/products-services/rights-and-licensing/permissions/

BMJ Case Report Fellows may re-use this article for personal use and teaching without any further permission.

Become a Fellow of BMJ Case Reports today and you can:

- Submit as many cases as you like

- Enjoy fast sympathetic peer review and rapid publication of accepted articles

- Access all the published articles

Re-use any of the published material for personal use and teaching without further permission

\section{Customer Service}

If you have any further queries about your subscription, please contact our customer services team on +44 (0) 2071111105 or via email at support@bmj.com.

Visit casereports.bmj.com for more articles like this and to become a Fellow 